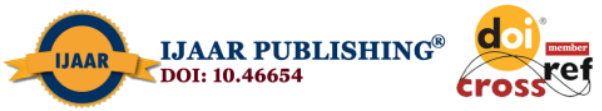

International Journal of Advanced Academic Research (Arts, Humanities and Education) | ISSN: 2488-9849

Vol. 6, Issue 12 (December, 2020) | www.ijaar.org

Journal DOI: 10.46654/ij.24889849

Article DOI: 10.46654/ij.24889849.a61242

\title{
IMPACT OF DOMESTIC VIOLENCE ON ACADEMIC PERFORMANCE BASE ON GENDER OF SENIOR SECONDARY SCHOOL STUDENTS IN JALINGO EDUCATION ZONE, TARABA STATE NIGERIA: IMPLICATIONS FOR COUNSELLING
}

\author{
Usman, Musa \\ Department of Guidance and Counselling, \\ Faculty of Education, \\ Taraba State University, Jalingo, PMB 1167, Jalingo Taraba State Nigeria \\ *Email: mustylala141@gmail.com
}

\begin{abstract}
This study investigated the impact of Domestic Violence on academic performance base on gender of Senior Secondary School Students' in Jalingo Education Zones of Taraba State. To guide the study, one research question and one null hypothesis were formulated. The design adopted for this study was descriptive survey research design. The population of the study consists of 362 students in SS2. The research instrument used is a questionnaire titled: Impact of Domestic Violence on Academic Performance of Students Base on Gender Questionnaire (IDVAPSBGQ). The reliability of the instrument was determined using Cronbach alpha method and yielded 0.785. The data collected wasanalysed using mean and standard deviation, while chi-square was used to test the hypothesis at 0.05 alpha significance level. The findings of the study revealed that: domestic violence has negative impact on the academic performance of both gender (boys and girls) of Senior Secondary Students. Recommendations and Implications for Counselling include: Awareness Campaigns be put in place, Domestic Violence Act be enacted in Nigeria to protect victims, Social work profession be legalized and bill passed into law. Guidance and Counselling therapy sessions be observed in schools and community level to educate, sensitize and rehabilitate individuals.
\end{abstract}

Keywords: Academic Performance, Domestic Violence, Gender and Impact 


\section{INTRODUCTION}

Domestic violence is devastating problem for those whose lives are affected by it. Thesocial, health and criminal justice agencies respond to it, and the wider society always bear the costs. Whilst domestic violence is not a new phenomenon, the past thirty years have seen increasing public awareness and a growing political consensus that something need to be done, even if what should be done is less clear (Holt and Devaney, 2015). Over time our understanding about the presentation, dynamics and impact of domestic violence has developed, resulting in the need to define what is it that society needs to tackle. This, however, has not been a trouble free endeavour, with definitions and understanding of violence varying across research studies, regions and cultural settings (European Union Agency for Fundamental Rights, 2014). Domestic violence is a global issue reaching across national boundaries as well as socio economic, culture, racial and class distinctions. Most contemporary scholars agree that domestic violence is one of the negative practices that mostly happen in household. This problem is not only widely dispersed geographically but its incidence is also extensive. Domestic violence is wide spread, deeply ingrained and has serious impact on students' health, and academic well-being. It is enormous, yet no other major problem of public well-being has been so widely ignored and so little understood as this phenomenon.

Currently, not many researches indicate that a child's age makes any significant difference in respect of whether they are more or less affected by their exposure to domestic violence, although the ways in which they are affected may differ. For example, babies living with domestic violence appear to be subject to higher levels of ill health, poorer sleeping habits and excessive screaming, along with disrupted attachment patterns. Children of pre-school age tend to be the age group who show most behavioural disturbance such as bed wetting, sleep disturbances and eating difficulties, and are particularly vulnerable to blaming themselves for the adult violence. Older children are more likely to show the effects of the disruption in their lives through under performance at school, poorly developed social networks, self-harm, running away and engagement in anti-social behaviour (Humphreys and Houghton, 2008). Several studies have shown that $60 \%$ to $70 \%$ of families in which a woman is battered, children are also battered. According to Graham Berman (2014), more than half of the school aged children in domestic violence shelters show clinical levels of anxiety or post-traumatic stress disorder without treatment, these children are significance of risks for delinquency, school dropouts and difficulties in their own relationships. Children may become withdrawn, non-verbal and exhibit regression behaviour such as clinging and whining, eating and sleeping difficulties, concentration problems. Unlike young children, the pre-adolescence child typically has greater ability to externalize negative emotions (i.e. to verbalize) in addition to symptoms commonly seen with childhood anxiety; victims within this age group may show a loss of interest in school, low self-esteem/ concept, avoidance of peer relations and opposition defiant behaviour in school setting.

Egunsola (2014) detect that, over a period of time, it has been observed that students exposed to the same lessons by the same teachers perform differently when they are evaluated. This shows that outside the school environment, other factors influence students' academic performance. Hence, many other uncontrolled variables can be responsible for academic performance of 
students. Generally, secondary school students inclusive, Parental variables are not exceptions from the factors responsible for academic performance.

\section{Statement of the Problem}

Senior secondary students in Jalingo Education zone of Taraba State seem to perform poorly. This is due to the fact that, the researcher observed exam failure is common among boys and girls who tend to experience domestic violence. Could the rate of domestic violence in Jalingo Education Zone comprising Ardo-kola, Lau and Jalingo Local Government Areas of Taraba State be responsible for the poor academic performance among boys and girls in senior secondary schools of Jalingo Education Zone Taraba State, Nigeria? What could the implication of this assumed trend be if not properly tackled?

\section{Purpose of the Study}

The purpose of this study is to determine the impact of domestic violence on academic performance based on gender by senior secondary school students in Jalingo Education Zone, Taraba State, Nigeria.

\section{Research Question}

One research question was formulated to guide the study.

What are the impacts of domestic violence on senior secondary school students in Jalingo education zonebase on gender?

\section{Statement of the Hypothesis}

One null hypothesis is postulated andtested at 0.05 level of statistical significance:

Ho1: Domestic violence has no significant impact on senior secondary school students' academic performance base on gender in Jalingo education zone.

\section{METHODOLOGY}

The research design adopted for this study is descriptive survey research design. According to Okogun (2016), irrespective of the types descriptive survey design collects information about a defined situation and condition or environment and the people.

The population of this study comprised of all the SSII students of 2018/ 2019 academic session in Jalingo Education zone of Taraba State. Available data from Taraba state Post Primary Management Education Board Jalingo (TSPPMEB), revealed that the zone has 44 senior secondary schools with a total enrolment of three-thousand eight-hundred and two. This study is limited to SSII students because they are the most current set of students on ground and they form the most stable class suitable for the purpose of the study. 
The sample size for this study is three hundred and sixty-two. Multi-stage sampling was used to select the sample size for the study using the Taro Yamane's (1976) formula for determining sample size of the entire population.

The main instrument for this study is questionnaire. Named "Impact of Domestic Violence on academic performance of students based on gender Questionnaire" (IDVAPSBGQ). The instrument was validated by (three) experts, Measurement and Evaluation, Guidance and Counselling and Science Education, Faculty of Education. A pilot study was carried out in (Two) schools in Taraba State which are not part of the sample of the study, but part of the population of the study. The IDVAPSBGQ was administered to forty (40) respondents. Cronbach Alpha co-coefficient was used to estimate internal consistency of the instrument. The reliability index of 0.785 was obtained. Descriptive statistics of mean and standard deviation was used in answering the research question using the SPSS package.

\section{Result}

Mean and standard deviations of rating items of the impacts of domestic violence on academic performance of senior secondary school students in Jalingo education zone $(\mathrm{N}=361)$
$\mathbf{S} / \mathbf{N}$
Statement
Mean SD Rem

1. Boys that experience domestic violence at home miss class.

$3.24 \quad 0.96 \quad$ A

2. Girls that experience domestic violence at home miss class

$3.06 \quad 0.92 \quad \mathrm{~A}$

3. Boys affected by domestic violence abscond from school

$3.04 \quad 0.98 \quad \mathrm{~A}$

4. Girls affected by domestic violence abscond from school

$3.03 \quad 0.95 \quad \mathrm{~A}$

5. Boys affected by domestic violence don't pay attention in class

$2.91 \quad 1.01 \quad \mathrm{~A}$

6. Girls affected by domestic violence don't pay attention in class

$3.08 \quad 0.92 \quad \mathrm{~A}$

7. Inability to do homework is high among boys that experience domestic violence

$2.77 \quad 1.02 \quad \mathrm{~A}$

8. Inability to do homework is high among girls that experience domestic violence

$2.96 \quad 0.95 \quad$ A

9. Exams failure is common among boys who tend to experience domestic violence

$3.15 \quad 0.92 \quad \mathrm{~A}$

10. Exams failure is common among girls who tend to experience domestic violence

$3.07 \quad 0.96 \quad \mathrm{~A}$

Source: Researcher's Field Survey 2019

Grand mean=3.03SD=0.10 


\section{Table 2}

Chi-Square Test of impact of domestic violence on senior secondary school students' academic performance base on gender in Jalingo education zone.

\begin{tabular}{|c|c|c|c|}
\hline & Value & of & $\begin{array}{l}\text { Asymp. } \\
\text { Sig. (2- sided) }\end{array}$ \\
\hline Pearson Chi-Square & $913.762^{\mathrm{a}}$ & 18 & .000 \\
\hline Likelihood Ratio & 440.680 & 18 & 1.000 \\
\hline Linear-by-Linear Association & .000 & 1 & .983 \\
\hline $\mathrm{N}$ of Valid Cases & 361 & & \\
\hline
\end{tabular}

From table 2, chi-square at 18 degree of freedom $\left(\chi^{2}=913.76, p=.000\right)$ signifies that there is statistically significant impact on senior secondary school students' academic performance base on gender in Jalingo education zone. Thus, null hypothesis that domestic violence has no significant impact on senior secondary school students' academic performance base on gender in Jalingo education zone is not retained.

\section{Discussion of Findings}

The findings of this study revealed that domestic violence has significant impact on academic performance of senior secondary school students in Jalingo education zone, Taraba state Nigeria. Also thehypothesistested confirmed that there is significant impact of domestic violence on students' academic performance based on gender in senior secondary school of Jalingo education zone Taraba State, Nigeria.

Paiko (2011) conducted a survey study in Lagos state, Nigeria On "violence against women". The target population comprised of all women working in the markets and other places of work, girls and young women in secondary schools and universities. The researchermadeuse of questionnaire and interviews to elicit responses from the respondents. The result of the finding shows that $64.4 \%$ of 45 women interviewed in the work place said they had been beaten by a partner (boyfriend or husband), 56.6\% of 48 interviewed market woman admitted experiencing such violence.

The study under review is related to present study in the design instrument for data collection and model of testing reliability on the other hand the studies varies in the area of study, scope of study, sampling procedure and population of the study. Because the study under review wascarriedout in Lagos state Nigeria while the current study is conducted in Taraba state Nigeria, in terms of scope the study under review covers a large scope Lagos city while this study covered one education zone.

In a Similar study carried out by Obi and Ozumba (2007) in Oyo state and other parts of Nigeria, on "the factors associated with domestic violence", Obi and Ozumba study is in agreement with that of Paikoin Lagos likewise this study becausethe result revealed that the incidence of 
domestic violence is high irrespective of gender. On the factors associated with domestic violence, in South East, Nigeria, $70 \%$ of respondents reported abuse in their family with $92 \%$ of the victims being female partners and the remaining $8 \%$ being male. Nevertheless, this study proves the findings of Westra and Martin (2011) who undertook a study in Tunis the capital city of Tunisia on "The effect of domestic violence on student academic performance." The findings of the study were as follows: children (ages 2-8 years) who have witnessed violence scored significantly lower in verbal, quantitative, motor and overall intellectual ability tests than from general population. The findings also show no significant differences on intelligence test scores between school age witnesses and no witnesses with similar demographic characteristics. The result obtained from questionnaire shows that child witnesses (ages 4-9 years; $n=38$ ) had significantly more learning problems according to maternal report than a control group of children $(n=42)$ from similar Socio-economic backgrounds. Spousal violence affects children's cognitive development and academic performance. The Study has proved that it decreases their academic performance as they find it difficult in concentrating in their studies.

\section{COUNSELLING IMPLICATIONS}

From research findings, counselling therefore would help students to develop self-awareness, this can also build relationships, improve and change their life. It helps the struggling students build their strength and be highly motivated. Learning situation then becomes a multidisciplinary environment where knowledge is acquired, skills developed and attitudeschanged.

The followingbe put in place with aim of helping the students:

Awareness campaigns: awareness campaign should be put in place, when students and parents become aware of the dangers and effects domestic violence has on their lives, it keeps the issue alive and important.

Domestic Violence Act: An Act should be enacted in Nigeria to protect victims of domestic violence and provide long term measures of prevention of domestic violence. Efforts should be made right from kindergarten, primary schools and colleges to inculcate more responsible behaviour at a tender age, and to teach and educate young people that violence is never acceptable behaviour.

There should be Guidance and Counselling Therapy sessions in both school and Community Level. This will educatesensitize and rehabilitate each and every individual in the society. This would also help students to cope with the trauma associated with the violence. The helping professionals should take responsibility of reporting the suspected abuse to the child protection agency or police; this would reduce the rate of violence since law will be applied effectively to apprehend offenders typically counsellors and school personnel should be required to report and be granted immunity from liability because they are presumed to be acting in good faith. 


\section{References}

Alam R. and Islam R., (2015). Factors affecting domestic violence against women in Bangladesh: European Journal of Public Health, Volume 25, Issue suppl_3, 1 October 2015, ckv175.013, https://doi.org/10.1093/eurpub/ckv175.013

Egunsola A. O. E. (2014). Influence of parental marital status, family type and size on academic performance of secondary school students in Agricultural science in Adamawa state, Nigeria. Journal of Humanities and Social Science (IOSR-JHSS), 19(11), Ver. IV, 63-68

European Union Agency for Fundamental Rights (2014). Violence against women: An EU survey. www.fra.europa.eu accessed on 18 November, 2018

Graham-Bermann, S (2014). Preventing domestic violence. University of Michigan research information index. UM-Research-WEB@umich.edu

Holt, S. \& Devaney, J. (2015), 'Understanding domestic abuse and sexual violence: Prevalence, policy and practice' in Healy, D., Hamilton, C., Daly, Y. and Butler, M. (Eds.), The Routledge Handbook of Irish Criminology, Oxford: Routledge

Humphreys, C. \& Houghton, C. (2008). Literature review: Better outcomes for children and young people experiencing domestic abuse- Directions for good practice. Www.gov.scot accessed on 19 November, 2018

Ministry of Education. 2018/2019 Session Report. Retrieved from post Primary School Management Board (PPSMB). Taraba State.

Obi S.N \& Ozumba B.C. (2007). Factors associated with domestic violence in south-east Nigeria. J ObstetGynaecol. 27(1):75-8

Okogun (2016). Literacy in Everyday Life: Results from the2003 National Assessment of Adult Literacy (NCES 2007-480).U.S. Department of Education. Washington, DC: National Center for Education Statistics.

Paiko, P. (2011). Violence against women in Lagos. Massachusetts: Bergin \& Garvey

Taro, Yamane (1976). Statistics: An introductory Analysis, $2^{\text {nd }}$ Edition, New York: Harper and Row

Westra, B., \& Martin, H. P. (2011). Children of battered women. Matern. Child Nurs. J.10: 4154 